\title{
Jerzy Ogonowski, Sytuacja prawna Żydów w Rzeczypospolitej Polskiej 1918-1939. Prawa cywilne i polityczne, Żydowski Instytut Historyczny, Warszawa 2012, pp. 161
}

In the Second Polish Republic, Jews constituted about 10 percent of the total population, being at the same time the largest national and religious minority in interwar Poland. Their greatest concentrations were in large cities such as Warsaw, Lodz, Krakow and Lvov, where they constituted more than 30 percent of the population. Therefore, interest in legal regulations concerning Jewish population is not surprising. Although the authorities in the interwar period attempted of legal regulations of, among others, the political and civil issues, still they related to individual solutions, and they were not part of a coherent, comprehensive policy towards the Jews. It should be emphasized that the legal situation of the Jewish minority in the years 1918-1939 was characterized by high volatility, which the reviewed study presents clearly.

Author of the monograph Jerzy Ogonowski was a historian of law, specializing in issues of political and legal national and religious minorities in Poland of the interwar period (1918-1939). The author of the monograph since the mid-seventies was associated with the circles of historians of law, University of Warsaw, where he originally dealt mainly with the public position of the Ukrainian minority in Poland. The culmination of his research on the historical and legal aspects of the language rights of minorities was a doctoral dissertation defended in 1996.

Another unexplored research area, on which Jerzy Ogonowski focused his investigations was the legal status of Jews in the Second Republic. Implemented in this field the research project resulted in this monograph and expansion of exploration in the direction of religious autonomy of Jews in Poland in the interwar years. The collected source materials and the results of their analysis gave the rise to the process of creating a synthetic monograph Związek wyznaniowy Żydów (gminy wyznaniowe żydowskie) w RP w latach 1918-1939, which is now (after the author's death in 2008) ready for publication. 
The book Sytuacja prawna Żydów w Rzeczypospolitej Polskiej 1918-1939. Prawa cywilne i polityczne, by Jerzy Ogonowski occupies an important position in the author's scientific achievements. At the same time, it is of paramount importance in bridging the historical and legal gap in literature on the history of Polish Jews in the twentieth century.

The discussed monograph is a synthetic analysis of the legal situation of the Jews residing on Polish territory in the years 1918-1939. The author presents a cross-section of political and civil rights of the Jewish minority in a substantive and systematical way. At the same time, this work enables to outline the volatile nature of the policy pursued by the Polish authorities towards the Jews in the interwar period.

The reviewed book publication is not a comprehensive study, but decidedly concise, based on a strong foundation of source documents. It consists of the initial elements of the monograph i.e. The foreword by prof. Michael Pietrzak, a short memo About the author inserted by the publisher and The list of abbreviations and Prolegomenon, which explains the fundamental concepts of civil and political law and the context in which they are used in the analysis. The main part of the study was written in two asymmetrical parts. The first one consists of three chapters, outlines the legal situation of the Jews in Poland before regaining independence. It also contains the characteristics of the Jewish minority in terms of abundance, distribution and the socio-professional structure and characteristics of the main cultural and political currents. In addition, the author presents the process of evolution of the character of Polish law towards the Jewish population.

The second part Problemy węzlowe (The key problems), much more extensive, including twelve chapters, oscillates around such content as the issues: citizenship, duties of the military, the language rights, changes of first names and surnames. In the meantime, the author outlined the circumstances of issuing identity documents to Jews, marriage and divorce process, and restrictions related to them. In addition, he pointed complications associated with registration of civil status, Jewish education, and prosperity of industry, trade and commerce. Moreover, the author supplemented this part with the issue of the civil service and the liberal professions, establishing societies, unions and associations, and communication with Palestine and the Jewish diaspora.

This study is an original look at the issues of the legal status of the Jewish minority in the interwar period in Poland, alongside it brings a valuable cognitive contribution to the poor so far literature. It is somehow a stimulating part of further research on the history of civil and political law in relation to national and religious minorities, especially the Jewish population. The publication largely complements the existing knowledge in the literature, especially thanks to its interdisciplinary nature it broadens the reader's awarness in the area of humanities and social sciences. 
The presented analysis is based on the extensive list of sources and literature. It should be emphasized that Jerzy Ogonowski based largely on archives and normative materials, and verdicts and judicial decisions, which determines the meticulousness of the research. Undoubtedly, the broad base of statistical materials, and studies contributed to this.

The author's visible care about maintaining a proper chronology of events and phenomena helps the reader to understand the cause-effect relationships. The content is additionally supplemented with graphic communication, which enriches the drawn picture of the interwar reality and its specific components. The deficit of conclusions that would present in a comprehensive manner the undertaken analysis should be pointed as the missing part. Moreover, the author completely failed to mention the questions concerning, for example, discrimination against Jews in culture and sport, especially in football, what most affected Jewish clubs in Krakow: Jutrzenka and Makkabi.

The publication can be a valuable source of knowledge, especially for law historians, political scientists and sociologists dealing with minorities and religious and politicolegal issues in relation to these groups. The narrative is conducted in a manner accessible to the recipient, so that the monograph can gain interest outside the scientific and academic circles. The analyzed content is a valuable material for further research, especially for law historians, political scientists and sociologists dealing with national and religious minorities, and political and legal issues in relation to these groups.

Wioletta Husar*

* Ph. D. student, Institute of Political Science, University of Zielona Gora. Mail: wiola2289@ o2.pl. 